\title{
PERAN KEPEMIMPINAN DALAM MENINGKATKAN DISIPLIN KERJA PEGAWAI DI KANTOR KECAMATAN GANDUS KOTA PALEMBANG
}

\author{
Amir Mahmud \\ Staf Dosen Fakultas Ilmu Administrasi Universitas Sjakhyakirti \\ Email : amir15mahmud@gmail.com
}

\begin{abstract}
ABSTRAK
Kepemimpinan merupakan kekuatan aspirasi, kekuatan semangat, dan kekuatan moral yang mampu mempengaruhipara anggota untukmengubah sikap, sehinggamerekamenjadi paham dengan keinginan pemimpin. Tingkah laku kelompok atau organisasi menjadi aspirasi pemimpin oleh penganuh interpersonal pemimpin terhadap anak buahnya. Masalah dalam penelitian ini adalah bagaimana peran kepemimpinan dalam meningkatkan disiplin kerja pegawai dan hambatan-hambatan yang dalam meningkatkan disiplin kerja pegawai.Tujuan dari penelitian ini adalah untuk mengetahui peran kepemimpinan dalam meningkatkan disiplin kerja pegawaidan untuk mengetahui hambatan-hambatandalammeningkatkandisiplinkerjapegawai.

Metode pengumpulan data yang digunakan dalam penelitian ini adalah metode analisis Deskriptif. Hasil penelitian ini menunjukkan bahwa peran pemimpin sangat berpengaruh dalam peningkatan kedisiplinan kerja pegawai di Kantor Kecamatan Gandus Kota Palembang guna mencapai keberhasilan kerja sebagaimana dengan tujuan awal instansi. Saran yang dapat diberikan adalah hendaknya pemimpin melakukan pembinaan untuk meningkatkan disiplin kerja pegawai dengan penyampaian motivasi dan pendekatan lebih intensif kepada para pegawai yang bermasalah dengan kedisiplinan.
\end{abstract}

\section{Kata Kunci : Kepemimpinan, Disiplin Kerja}

\section{Pendahuluan \\ Latar Belakang}

Organisasi merupakan suatu sistem yang di dalamnya terdapat hubungan kerja sama antar sekelompok orang untuk mencapai suatu tujuan. Salah satu faktor yang mendukung keberhasilan suatu organisasi adalah dengan adanya manajemen sumber daya manusia (SDM).

Sumber daya manusia yang berkualitas adalah manusia yang mempunyai keterampilan, kemampuan, dan etos kerja yang tinggi. Setiap lembaga atau instansi memerlukan pegawai yang memiliki kepribadian tinggi dan memiliki kemampuan serta kecakapan dalam mengambil keputusan. Penerapan disiplin bertujuan agar kedisiplinan dapat ditingkatkan oleh para pegawai dilembaga atau instansi tersebut memiliki produktivitas yang tinggi. Salah satu bentuk optimalisasi pengelolaan SDM adalah peran kepemimpinan.

Kepemimpinan merupakan suatu kekuatan aspirasional, kekuatan semangat, dan kekuatan moral yang kreatif yang mampu mempengaruhi para anggota untuk mengubah sikap sehingga mereka menjadi paham dengan keinginan pemimpin.

Kepemimpinan berfungsi sebagai penggerak dan koordinator dari sumber daya manusia, sumber daya alam, semua dana, dan sarana yang disiapkan oleh sekumpulan manusia yang melakukan kerja sama guna bertingkah laku dalammencapai tujuan.

Kepemimpinan dalam suatu organisasi mempunyai dampak cukup luas termasuk perilaku pegawai, kepemimpinan yang mampu menggerakkan dan meningkatkan kinerja pegawai. Namun, sebaliknya kepemimpinan yang tidak mendapat dukungan dari pegawai kemungkinan membuat pegawai akan bekerja dengan malas karena rasa kurang simpati kepada pemimpin.

Pengawasan yang dilakukan oleh atasan terhadap pegawai memungkinkan pegawai dapat bekerja lebih baik, demikian halnya dengan penerapan disiplin terhadap pegawai tentunya dapat membentuk pribadi pegawai yang bertanggung jawab sehingga pekerjaan dapat terlaksana dengan efektif dan efisien. Hal ini seperti dinyatakan oleh 
Handoko (2003: 361) pengawasan dirancang membutuhkan tata tertib yang mempunyai tujuan untuk mengantisipasi masalahmasalah atau penyimpangan-penyimpangan dari standar atau tujuan yang telah digariskan. Faktor pentingnya kedisiplinan merupakan pelaksanaannya dimulai dari para pegawai itu sendiri.Disiplin merupakan suatu kepatuhan dari orang-orang dalam suatu organisasi terhadap peraturan-peraturan yang telah ditetapkan sehingga menimbulkan keadaan tertib. Disiplin disini adalah mengenai disiplin kerja, waktu kerja dan disiplin dalam mentaati peraturan yang sudah ditetapkan. Kesadaran tinggi diperlukan dalam melaksanakan aturan yang dapat diwujudkan dalam disiplin kerja yangtinggi,untukmencapai tingkatproduktivitas.

Disiplin yang baik mencerminkan besamya rasa tanggung jawab seseorang terhadap tugas-tugasnya yang diberikan kepadanya.Hal ini mendorong gairah kerja, semangat kerja, dan terwujudnya tujuan perusahaan, karyawan, dan masyarakat. Permasalahan kedisiplinan khususnya kedisiplinan pegawai, hingga saat ini masih mendapat sorotan yang tajam dari masyarakat.Pelanggaran maupun permasalahan kedisiplinan pegawai telah menghambat fungsi pelayanan pemerintah.

Peraturan Disiplin Pegawai Negeri Sipil diatur dalam Peraturan Pemerintah Nomor 30 Tahun 1980 tentang Peraturan Disiplin Pegawai Negeri Sipil yang diperbahanui dengan dalam Peraturan Pemerintah Nomor 53 Tahun 2010. Dalam Peraturan Disiplin PNS diatur ketentuanketentuan mengenai: Kewajiban, larangan, Hukuman disiplin, Pejabat yang berwenang menghukum, Penjatuhan hukuman disiplin, Keberatan atas hukuman disiplin, Berlakunya keputusan hukuman disiplin. Dengan adanya peraturan tersebut setiap pegawai negeri sipil termasuk guru wajib mentaati segala peraturan tersebut, namun pada kenyataannya banyak pegawai negeri sipil, khususnya guru yang melakukan pelanggaran disiplin diantaranya dalam bentuk ketidak tepatan waktu datang dan pulang kerja, pelanggaran terhadap pelaksanaanatugas, dan tidakmentaatiperaturanyangberlaku.

Kecendenungan yang terjadi di lapangan terkait dengan kedisiplinan pegawai sebagaimana hasil pengamatan sementara yang dilakukan di Kantor Kecamatan Gandus Kota Palembang, menunjukkan adanya berbagai persoalan kedisiplinan. Salah satu faktor dalam menerapkan disiplin kerja adalah dengan memberikan hukuman/sanksi dan hal ini sangat diperlukan dalam meningkatkan kedisiplinan kerja.Demikian halnya dengan Pemerintahan Kecamatan Gandus Kota Palembang yang salah satu tujuan utamanya adalah memberikan pelayanan yang efektif dan efisien kepada masyarakat secara maksimal dan salah-satu indikator dalammewujudkannya dengan meningkatkandisiplinkerjapegawai.

Namun pada kenyataannya, disiplin kerja tidak lepas kaitannya dengan bagaimana pimpinan menjalankan perannya sebagai kepala organisasi.Pimpinan dinilai memegang peranan yang penting dan strategis terhadap disiplin kerja pegawai sesuai dengan tugas pokok dan fungsinya.Kepemimpinan dinilai penting dalam menegakkan disiplin kerja pegawai.Almitraf (2015:66) untuk tercapinya disiplin kerja pegawai, hal ini tidak lepas dari pengaruh pimpinan dalam organisasi, peran pimpinan sangat sentral sebagaimana dikemukakan Siagian (1982: 36), "Bahwa sukses tidaknya seseorang dalam melaksanakan tugas kepemimpinanannya, tidak saja ditentukan oleh keterampilan teknis yang dimilikinya, namun juga ditentukan oleh keahlian dalam menggerakkan bawahan untuk bekerja". Dengan kata lain seorang pemimpin harus memperhatikan disipin kerja pegawainya dengan mengingat pentingnya disiplin kerja dalam diri pegawai saat bekerja yang benujung pada proses pencapaian tujuan organisasi tersebut. Dari uraian diatas tersebut penulis tertarik untuk melakukan penelitian dengan judul :" Peran Kepemimpinan dalam meningkatkan disiplin kerja pegawai di Kantor Kecamatan Gandus Kota Palembang “.

\section{Rumusan Masalah}

Berdasarkan latar belakang yang telah diuraikan maka permasalahan dalam penelitian ini adalah:

1. Bagaimana Peran kepemimpinan dalam meningkatkan disiplinkerja pegawai di Kantor Kecamatan GandusKotaPalembang?

2 Apa saja hambatan yang ditemui pimpinan dalammeningkatkan disipllinkerja pegawai di Kantor Kecamatan Gandus KotaPalembang?

\section{Tujuan Penelitian}

Adapun tujuan Penelitian ini adalah : 
1. Untuk mendeskripsikan peran kepemimpinan dalam meningkatkan disiplin kerjapegawai di Kantor Kecamatan Gandus KotaPalembang.

2 Untuk mengetahui hambatan yang ditemui pimpinan dalam meningkatkan disiplin kerja pegawai di Kantor Kecamatan Gandus Kota Palembang.

\section{LANDASAN TEORI}

\section{Pengertian Kepemimpinan}

Kepemimpinan berasal dari kata pemimpin yang berarti seorang pribadi yang memiliki kecakapan dan kelebihan khususnya kecakapan dan kelebihan di satu bidang sehingga dia mampu mempengaruhi orang lain untuk bersama-sama melakukan aktifitas tertentu demi pencapaian suatu sasaran dan tujuan. (Kartono, 2005 :76).

Sutrisno (2009: 213), dalam suatu organisasi, kepemimpinan memegang peranan yang penting karena pemimpin itulah yang akan menggerakkan organisasi dalam mencapai tujuan organisasi. Tidak mudah menjadi seorang pemimpin, karena pempimpin harus memahami bawahan.

Menurut Tead; Terry; Hoyt (dalam Kartono, 2003) Pengertian Kepemimpinan yaitu kegiatan atau seni mempenganuhi orang lain agar mau bekerjasama yang didasarkan pada kemampuan orang tersebut untuk membimbing orang lain dalam mencapai tujuan-tujuan yang diinginkankelompok.

B.HRaven dalam Wiryana dan Supardo( 2005:4), mendefinisikan pemimpin sebagai seseorang yang menduduki suatu posisi di kelompok, mempengaruhi orang-orang dalam kelompok itu sesuai dengan ekspektasi peran dari posisi tersebut dan mengkoordinasi serta mengarahkan kelompok untuk mempertahankan diri sertamencapai tujuankelompok, organisasi dan masyarakat. Pengertian tersebut mengandung beberapa unsur pokok, yaitu:Kepemimpinan harus melibatkanoranglain,
1) Kepemimpinan merupakan suatu faktor pada diri seseorang yang dapat ditumbuhkan, dipupukdandikembangkan.

2) Pemimpin dapat mempeganuhi pengikut atau bawahannya dan juga dapat memberikan pengarahan yang sesuai dengan tujuan yang hendakdicapai

Dari beberapa pengertian diatas dapat kita simpulkan bahwa kepemimpinan menupakansuatu kegiatan yang dilakukan seseorang dalam upaya mempengaruhi orang lain baik individu maupun kelompok guna mencapai tujuan yang telah ditentukan.Untuk mengetahui pemimpin dalam melaksanakan kepemimpinan penulis melihat sudut pandangpada gaya, tipe, dansifatkepemimpinan.

\section{Gaya Kepemimpinan}

Peranan kepemimpinan dalam kehidupan sederhana Iebih mudah dikenal, bila dilirik pada masyarakat modem yang sudah maju telah ada spesialis-spesialis kemampuan, spesialis-spesialis dapat dipastikan menurut sistem dalam penunjukkan atau pengangkatan pemimpin dapat dilaksanakan.

Gaya kepemimpinan yang tepat sesuai dengan tujuan perusahaan menurut Hasibuan (2002:172), gaya kepemimpinan dibagi menjadi 4, yaitu:

1. Gaya Kepemimpinan Otoriter Kepemimpinan otoriter adalah jika kekuasaan atau wewenang, sebagian besar mutlak tetap berada pada pimpinan dalam pengambilan keputusan dan kebijaksanaan hanya ditetapkan sendiri oleh pemimpin, bawahan tidak diikut sertakan untuk memberikan saran, ide, dan pertimbangan dalamprosespengambilankeputusan.

2 Gaya Kepemimpinan Partisipatif Kepemimpinan partisipatif adalah apabila dalam kepemimpinannya dilakukan dengan cara persuasif,menciptakan kerja sama yang serasi, menumbuhkan loyalitas, dan partisipasi para bawahan. Pemimpin memotivasi bawahan agar merasa ikut memilikiperusahaan.

Pemimpin dengan gaya partisipatif akan mendorong kemampuan bawahan mengambil keputusan, dengan demikian, pemimpin akan selalu membina bawahan 
untuk menerima tanggung jawab yang lebih besar.

3. Gaya Kepemimpinan Delegatif Kepemimpinan delegatif apabila seorang pemimpin mendelegasikan wewenang kepada bawahan dengan agak lengkap, dengan demikian, bawahan dapat mengambil keputusan dan kebijaksanaan dengan bebas atau leluasa dalam melakukan pekerjaannya Pemimpin tidak peduli cara bawahan mengambil keputusan dan mengerjakan pekerjaannya, sepenuhnya diserahkankepadabawahannya.

4. Gaya Kepemimpinan Situasional

Kepemimpinan situasional, tidak ada satu pun cara yang terbaik untuk mempenganuhi orang lain. Gaya kepemimpinan mana yang harus digunakan terhadap individu atau kelompok tergantung pada tingkat kesiapan orangyangakandipengaruhi.

\section{FungsiKepemimpinan}

Berbagai kriteria digunakan untuk menilai efektifitas kepemimpinan se seorang. Kriteria tersebut berkisar pada kemampuan pimpinan berperan dalam men jalankan berbagai fungsi-fungsi kepemimpinan, sebagaimana dikemukakan oleh Siagian (2003) sebagaiberikut:

1. Pimpinan selaku penentu arah yang akan ditempuhdalamusahapencapaiantujuan

2. Wakil dan juru bicara organisasi dalam hubungan dengan pihak-pihak di luar organisasi.

3. Pimpinanselakukomunikatoryangefektif

4. Mediator yang andal, khususnya dalam hubungan ke dalam, terutama dalam menanganisituasikonflik.

5. Pimpinan selaku integrator yang efektif, rasional, objektif, dannetral.

Kartono (2005), yaitu bahwa fungsi kepemimpinan ialah memacu, menuntun dan membimbing, membangun dan memberi atau membangun motivasi-motivasi kerja, mengendalikan organisasi, menjalin jaringanjaringan komunikasi yang baik, memberikan supervisi/pengawasan yang efisien dan membawa para pengikutnya kepada sasaran yang ingin dituju sesuai dengan ketentuan waktu dan rencana.

\section{Disiplin Kerja \\ PengertianDisiplinKerja}

Disiplin menupakan bentuk pelatihanyang menegakkan peraturan-peraturan perusahaan dimana pegawai bekerja (Mathis, 2000: 314).Disiplin kerja menurut Sastrohadiwiryo (2002: 297) adalah suatu sikap menghormati,menghargai, patuh dan taat terhadap peraturan-peraturan yang berlaku, baik yangtertulis maupuntidak tertulis serta sanggupmenjalankannya dantidakmengelakuntuk menerima sanksi-sanksinya apabila dia melanggar tugasdan wewenangyangdiberikankepadanya.

Menurut Hasibuan (2005 : 193) Disiplin yang baik mencerminkan besarnya rasa tanggung jawab seseorang terhadap tugas-tugas yang diberikan kepadanya.Hal ini mendorong gairah kerja, semangat kerja, dan terwujudnya tujuan perusahaan, karyawan, dan masyarakat.Ini berarti disiplin memegang peranan penting dalam rangka meningkatkan produktivitas kerja pegawai. Peningkatan disiplin kerja akan diikuti dengan peningkatan produktivitas kerja. Salah satu tujuan perusahaan adalah meningkatkan produktivitas kerja pegawai, dengan demikian disiplin akan mempercepattujuan perusahaanatauorganisasi.

Disiplin kerja merupakan kegiatan manajemen untuk menjalankan standar-standar organisasional (Hani Handoko 2003: 208).Disiplin menunjukkan suatu kondisi atau sikap hormat yang ada pada pegawai atau karyawan terhadap peraturan-peraturan yang ditetapkan oleh perusahaan(EdySutrisno 2009:89). Olehkarenaitu, setiap pimpinan selalu berusaha agar para bawahannya mempunyai disiplin yang baik.Untuk memelihara dan meningkatkan kedisiplinan yang baik adalah hal yang sulit, karena banyak faktor yangmempengaruhinya.

Tindakan disiplin adalah pengurangan yang dipaksakan oleh pimpinan terhadap imbalan yang diberikan oleh organisasi karenaadanya suatu kasus tertentu.Tindakan disiplin ini tidak termasuk pemberhentian sementara atau penurunan jumlah tenaga kerja yang disebabkan oleh pengurangan anggaran atau produktivitas atau pelanggaranpelanggaran aturan instansi. Disiplin mengacu pada pola tingkah laku, dengan ciri-ciri yaitu: adanya hasrat yang kuat untukmelakukan sepenuhnya apa yang sudah menjadi norma, etika kaidah yang berlaku, adanya perilaku yangterkendali danadanya ketaatan.

Tidakan disiplin ini dapat berupa teguranteguran, penskoran, penurunan pangkat atau gaji dan pemecatan.Tindakan-indakan ini disebabkan oleh kejadian-kejadian perilakukhusus dari pegawai yang menyebabkan rendahnya produktivitas atau 
pelanggaran - pelanggaran instansi (Gomes, 2002:232).

Menurut Prijodarminto (1999 : 23), yang dimana disiplinitu mempunyai tiga aspek, Yaitu :

1. Sikapmental(mentalattitude)

2 Pemahaman yang baik mengenai sistem aturan perilaku, norma, kriteria, dan standar yangsedemikianrupa.

Sikap kelakuan yang secara wajar menunjukkan kesungguhan hati, untuk mentaati segala hal secara cermat dan tertib

\section{Jenis-Jenis DisiplinKerja}

Handoko (2003: 208), disiplin dapat

dibedakanmenjadi 2 yaitu:

1. DisiplinPreventif

2 DisiplinPreventif

Bentuk-bentuk disiplin Simamora

(2004:749)adalahsebagaiberikut:

1. DisiplinManajerial

2 DisiplinTim

3. DisiplinDini

\section{Pendekatan dalam Disiplin Kerja}

Disiplin yang terbaik adalah jelas disiplin diri, karena sebagian besar orang memahami apa yang diharapkan dari dirinya di pekerjaan dan biasanya karyawan diberi kepercayaan untuk menjalankan pekerjaannya secara efektif. Adapun pendekatan-pendekatan dalam disiplin kerja karyawan (Mathis dkk, 2000:314) adalah:

1. Pendekatandisiplinpositif

Pendekatan disiplin positif dibangun berdasarkan filosofi bahwa pelanggaran merupakan tindakan yang biasanya dapat dikoreksi secara konstruksi tanpaperlu hukuman. Dalampendekatan ini fokusnya adalah pada penemuan fakta dan bimbingan untuk mendorong perilaku yang diharapkan, dan bukannya menggunakan hukuman (penalti) untuk mencegah perilaku yang tidak diharapkan. Kekuatan pendekatan positif ini dalam displin adalah fokusnya pada pemecahan masalah. Juga, karena karyawan merupakan partisipan aktif selama proses tersebut, maka perusahaan yang menggunakan pendekatan ini cendenung memenangkan tuntutan hukum jika karyawan mengajukan tuntutan. Kesulitan utama dengan pendekatan positif terhadap disiplin adalah jumlah waktu yang sangat lama untuk melatih para supervisordanmanajeryangdiperlukan.

2 PendekatanDisiplinProgresif

Disiplin progresif melembagakan sejumlah langkah dalam membentuk prilaku karyawan.
Kebanyakan prosedur disiplin progresif menggunakan peringatan lisan dan tulisan sebelum berlanjut ke PHK, dengan demikian, disiplin progresif menekankan bahwa tindakan-indakan dalam memodifikasi prilaku akan bertambah berat secara progresif (bertahap) jika karyawan tetap menunjukkan prilaku yang tidak layak. Seorang karyawan diberikan kesempatan untuk memperbaiki kesalahannya sebelum diberhentikan, dengan mengikuti urutan progresif akan memastikan bahwa sifat dan keseriusan maslah telah dikomunikasikan dengan jelas kepada karyawan.

\section{Faktor-faktor yang Mempengaruhi Disiplin Kerja}

Pada dasamya banyak indikator yang dapat mempengaruhi tingkat kedisiplinan karyawan suatu organisasi diantaranya(Hasibuan, 2002: 195)

1. Tujuandan Kemampuan

Tujuan dan kemampuan dalam suatu organisasi harus jelas dan ditetapkan secara ideal serta cukup menantang bagi kemampuanpegawai.

2 Kepemimpinan

Kepemimpinan sangat berperan dalam menentukan kedisiplinan karyawan, karena pimpinan dijadikan teladan dan panutan oleh para bawahannya. Pimpinan jangan mengharapkan kedisiplinan bawahannya baik jika dia sendiri kurang disiplin.

3. BalasJasa

Balas jasa (gaji dan kesejahteraan) ikut mempengaruhi kedisiplinan karyawan karena balas jasa akan memberikan kepuasan dan kecintaan karyawan terhadap perusahaan / pekerjaannya.

4. Keadilan

Keadilan harus diterapkan dengan baik pada setiap perusahaan supaya kedisiplinan karyawan perusahaan baik pula.

5. Waskat

Waskat (pengawasan melekat) adalah tindakan nyata dan paling efektif dalam mewujudkan kedisiplinan karyawan perusahaan. Karyawan merasa mendapat perhatian, bimbingan, petunjuk, pengarahan, dan pengawasan dari atasannya. 
6. Sanksi

Sanksi hukuman yang semakin berat, karyawan akan semakin takut melanggar peraturan-peraturan perusahaan, sikap, perilaku indisipliner karyawan akan berkurang.

7. Ketegasan

Pimpinan harus berani dan tegas, bertindak untukmenghukum setiap karyawan yang indisipliner sesuai dengan sanksi hukuman yang telahditetapkan. Ketegasan pimpinan menegur dan menghukum setiap karyawan yang indisipliner akan mewujudkan kedisiplinan yang baik pada perusahaantersebut.

8. Hubungan Kemanusiaan

Hubungan-hubungan baik bersifat vertikal maupun horizontal yang terdiri dari direct single relationship, direct group relationship, dan crossrelationship hendaknya harmonis.

\section{Hal yang diperhatikan dalam Meningkatkan Disiplin Kerja}

Dalam pendisiplinan kerja ada beberapa faktor yang perlu diperhatikan ( Haidjrachman, dkk, 2002:241):

1. Pembagian tugas dan pekerjaan telah dibuat lengkap dan dapat diketahui dengan sadar olehparapekerja.

2 Adanya petujuk kerja yang singkat, sederhanadanlengkap.

3. Kesadaran setiap pekerjaan terhadap suatu tugas atau pekerjaan yang menjadi tanggung jawabnya.

4. Perlakuan adil terhadap setiap penyimpanganolehmanajer.

5. Adanya keinsyafan para pekerja bahwa akibat dari kecerobohan atau kelalaiandapat merugikan organisasi dan dirinya serta ada kemungkinanmembahayakanoranglain.

\section{Hubungan kepemimpinan dengan disiplin kerja pegawai.}

Berjalannya proses penyelenggaraan pemerintahan dalam memberikan pelayanan yang efektif dan efisien maka sangat dibutuhkan disiplin pegawai dalam mewujudkannya, dimana hal ini tidak dapat berjalan dengan sendirinyatanpa adanya kepemimpinanCamat sebagai kepala pemerintahan kecamatan.
Camat sebagai seseorang yang memiliki wewenang dan tanggung jawab terhadap penyelenggaraan pemerintahan kecamatan harus mampu berperan dalam mengawasi, membina, mengarahkan terhadap disiplin kerja pegawai yang baik dan benar untuk mendukung kinerja yang unggul dalam memberikan pelayanan yang efektif danefisien terhadap masyarakat.

Kiranya tidak dapat disangkal bahwa keberhasilan suatu organisasi baik sebagai keseluruhan maupun berbagai kelompok dalam suatu organisai tertentu sangattergantungpadamutu kepemimpinan yang terdapat didalam organisasi yang bersangkutan.Karena kepemimpinan memainkan peranan yang dominan dan mempunyai kewenangan, kekuasaan dalam keseluruhan upaya untuk menciptakan disiplin kerja pegawai.

\section{METODE PENELITIAN Pendekatan Penelitian}

Dalam penelitian ini peneliti akan menggunakan pendekatan penelitian kualitatif yaitu penelitian yang dimaksudkan adalah untuk memahami fenomena tentang apa yang dialami oleh obyek penelitian dengan cara deskripsi dalam bentuk kata-kata, pada suatu konteks khusus yang alamiah (Lexy Moleong, 2007:6).

\section{Metode Penelitian}

Metode yang digunakan dalam penelitian ini adalah deskriptif dengan studi kasus. Dengan metode studi kasus diharapkan peneliti mampu mendeskripsikan secara mendalam tentang peran kepemimpinan dalam meningkatkan disiplin kerja pegawai di Kantor Kecamatan Gandus Kota Palembang.

\section{Lokasi Penelitian}

Dalam melakukan penelitian untuk karya ilmiah ini yang menjadi objek penelitian ini adalah Kantor Kecamatan Gandus Kota Palembang.

\section{SubyekPenelitian}

Dalam penelitian ini yang menjadi subjek penelitian adalah kepala instansi dan pegawai atau staff Kantor Kecamatan Gandus Kota Palembang, yag terdiri atas 14 orang.

\section{Jenis Data}

Jenisdata yang digunakan dalampenelitian adalah:

\section{DataPrimer}


Data primer dalam penelitian ini di dapat dari hasil wawancara danobservasi.

2 DataSekunder

Data sekunder dalam penelitian ini didapat secara tidak langsung berupa: sejarah Kantor Kecamatan Gandus, Sejarah Kecamatan Gandus, visi dan misi, struktur organisasi, tupoksi, absensi dan data lain yangmendukungpenelitian.

\section{TeknikPengumpulan Data}

Untuk mengungkapkan data tentang kedisiplinan kerja, maka penelitian ini menggunakan metode sebagai berikut:

1. MetodeObservasi

2 MetodeWawancara

3. MetodeDokumentasi

\section{Teknik Analsis Data}

Dalam penelitian kualitatif, data di analisis pada saat pengumpulan data dan setelah selesai pengumpulan data. Analisa data pada penelitian kualitatif dijelaskan dalam tiga langkah yaitu

1. Reduksidata

Reduksi data berupa pemilihan dan penyederhanaan untuk pemusatan perhatian.

2 Penyajian data berupa deskripsi kumpulaninformasi

Data yang telah direduksi disajikan dalam bentuk deskriptif. Penyajian data penelitian kualitatif bisa dilakukan dalam bentuk uraian singkat, bagan, hubungan antar kategori, dan sejenisnya. Hal ini dilakukan untuk menjelaskan sekaligus menjawab pertanyaan penelitian tentang bagaimana peran kepemimpinan dalam meningkatkan disiplin kerja pegawai.

3. Penarikankesimpulan

Penarikan kesimpulan merupakan kegiatan analisis data yang dimaksudkan untuk mencari maknadan membuat kesimpulan dari data yang telah dikumpulkan dengan mencari pola, tema, hubungan, persamaan, hal-hal yang sering timbul dan hipotesis kerja. Padaawalnyakesimpulantersebutmasih tentatif, akan tetapi dengan bertambahnya data dan melalui verifikasi yang terus dilakukan selama penelitian berlangsung maka kesimpulan tersebut menjadi lebih mendalam dan akurat. Pada penelitian ini, dengan menganalisis faktor-faktor yang menghambat peningkatan disiplin kerja, maka dapat ditemukan langkah selanjutnya yang menjadi dasar rekomendasi.

\section{Pemeriksaan Keabsahan Data}

Adapun teknik pemeriksaan yang digunakan untuk memeriksa keabsahan data dalam penelitian ini adalah triangulasi. Artinya dilakukan pengecekan data terhadap berbagai sumber, berbagai teknik pengumpulan data, dan dalam waktu yang berbeda. Dalam penelitian ini dilakukan triangulasi sumber dan metode. Peneliti membandingkan data dari beberapa teknik pengumpulan data untuk mengetahui keabsahan data. Jika hasilnya sama dari beberapa sumber/ informandan dari beberapa metode yang digunakan berartipenelititelahmemperolehkeabsahandata.

\section{HASIL PENELITIAN}

Peran Kepemimpinan Dalam Meningkatkan Disiplin Kerja Pegawai di Kantor Kecamatan GandusKotaPalembang

Berdasarkan hasil penelitian yang di lakukan di ketahui untuk meningkatkan disiplin kerja pegawai di Kantor Kecamatan Gandus Kota Palembang dilaksanakan melalui perbaikan dari berbagaiaspek, antaralain:

\section{Frekuensi Keterlambatan Masuk Kantor dalamSeminggu}

Sudah hal umum seorang pegawai dituntut untuk disiplin, masuk pagi dan pulang pada siang hari. Sudah tidak ditemukan adanya pegawai yang terlambat masuk kerja. Hasil penelitian mengenai keterlambatan masuk kantor dalam seminggu menunjukkan bahwa sebagian besar informan menyatakan tidak pernahterlambat masuk kantor.

\section{Meninggalkan Ruangan Kerja pada Jam} KerjaTanpaSeijinPimpinan

Memang tidak sepatutnya dilakukan oleh seorang pegawai meninggalkan pekerjaan yang menjadi tanggungjawabnya tanpa seijin dari atasan. Namun kadang hal ini terjadi karena berbagai alasan.

\section{Pulangawalpadaharikerja}


Sangat disayangkan seorang pegawai pulang kerja tidak sesuai jadwal yang telah ditetapkan. Karena jika hal ini terjadi akan mengakibatkan terbengkalainya pekerjaan di kantor, sehingga menyebabkan pelayanan kepadamasyarakatmenjaditidakmaksimal.

\section{Ketepatan Waktu Penyelesaian Pekerjaan}

Ketepatan waktu penyelesaikan pekerjaan merupakan ukuran bagi seorang pegawai dalam hal kedisiplinan. Pekerjaan yang diselesaikan tepat pada waktunya akan membuat pelaksanaan pekerjaan yang lain tidak terbengkalai.

5 Usaha Pelaksanaan Tugas sesuaidengan PeraturanKerja

Peraturan kerja digunakan untuk menciptakan kondisi yang kondusif. Peraturan dibuat untuk membuatkelancaran pekerjaan, bagaimana agar suatu tugas pekerjaan dapat diselesaikan tepat pada waktunya sehingga tujuan organisasi dapat dicapai. Dari hasil penelitian mengenai pelaksanaan tugas bahwa sebagian besar pegawai yang menyatakan berusaha dalam melaksanakan tugas sesuai peraturan kerja dan pegawai yang sangat berusaha memenuhi peraturan kerja dalam melaksanakan suatu pekerjaan. Hal tersebut menunjukkan bahwa usaha pelaksanaan tugas sesuai dengan peraturan kerja dapat dikategorikanbaik.

6 Penggunaan Pakaian Dinas dan Atribut ketikaDatangkeKantor

Setiap pegawai ketika bekerja dituntut kerapian dan kesopanannya sebagai upaya untuk menarik simpati pihak yang berhubungan. Dan sudah merupakan kewajiban menggunakan seragam dan atribut. Cerminan dari kedisiplinan pegawai dalam penggunaan pakaian dinas beserta atributnya tergambar dalam.

Dari hasil penelitian mengenai penggunaan pakaian dinas dan atribut ketika datang ke kantor menyatakan bahwasemua pegawai menyatakan selalu menggunakan pakaian dinas lengkap dengan atributnya ketikadatangkekantor.

Selanjutnya berhubungan dengan peran kepemimpinan, diperoleh hasil penelitian sebagai berikut :

1. Peranpemimpinsebagaifigur
Hasil penelitian menunjukkan bahwa Camat Gandus dalam menjalankan peran pemimpin sebagai figur sudah cukup baik. Terbukti Camat Gandus dapat menjalankan perannya sebagai figurehead, yakni peranan yang dilakukan untuk mewakili organisasi yangdipimpinannya di dalam setiap kesempatan dan persoalan yang timbulsecara formal.

2 Peranpemimpinsebagaipenggerak

Dari hasil penelitian menunjukkan bahwasanya dalam menjalankan perannya pemimpin sebagai penggerak sudah cukup baik. Hal ini dibuktikan oleh Camat Gandus dalam menggerakkan bawahannya.

3. Peran pemimpin sebagaipenghubung Berdasarkan hasil penelitian dapat dikatakan bahwa peran pemimpin sebagai penghubung sudah cukup baik dilaksanakan oleh camat, dibuktikan dengan terjalinnya kerjasama yang baiksesamapegawai.

4. Sebagaidisseminator(pemberiinformasi)

Dari hasil penelitian yang dilakukan dapat dikatakan bahwa peran pemimpin sebagai pemberi informasi sudah cukup baik. Hal ini terlihat dalam melakukan penyampaian informasi dari luar ke dalam organisasinya, dan informasi yang berasaldaribawahan atau stafnya kebawahanataustaflainnya.

5. Peran sebagaipengambilkeputusan Berdasarkan hasil penelitian dan wawancara yang dilakukan dapat dikatakan bahwa peran pemimpin dalam pengambil keputusan sudah cukup baik. Terbukti dengan adanya suatu keputusan yang terbaik dan tegas dalam menyelesaikan masalah maupun pengambilan suatukebijakan

Dari hasil penelitian juga menunjukan bahwa disiplin kerja pegawai di Pemerintah kecamatan Gandus Kota Palembang sebagian masih tergolong baik, dan ada juga penilaian tergolong buruk. Diambil dari pengambilan data kepada para informan terutama dari informan pegawai negeri, manajemen, dan pimpinannya. Bahwa disiplin yang ditunjukan mereka mendapati berbagai perilaku yang baik maupun perilaku yang buruk.

\section{Hambatan-Hambatan Yang Ditemui Dalam Menigkatkan Disiplin Kerja Pegawai Di Kantor KecamatanGandusKotaPalembang \\ Hambatan yang dialami Camat Gandus untuk meningkatkan disiplin kerja pegawai adalah kesadaran pegawai yang masih kurang akan}


pentingnyakedisiplinan dalamjam kerja. Kesadaran pegawai umumnya berbeda-beda antara pegawai yang satu dengan yang lainnya dan pada dasarnya lahir dari niat yang sunggu-sungguh dari hati pegawai itu sendiri. Kurangnya kesadaranini terlihat dari masih ada pegawai yang meninggalkan ruangan kerja tanpa izin Camat atau pulang kantor lebihawal.

Untuk mengatasi hambatan tentang kurangnya kesadaran dan kurangnya tanggung jawabini,Camathendaknyamelakukanpembinaan untuk meningkatkan disiplin kerja pegawai dengan penyampaian motivasi dan pendekatan lebih intensif kepada para pegawai yang bermasalah dengankedisiplinan.

\section{KESIMPULAN}

Berdasarkan hasil penelitian mengenai

Peran Kepemimpinan dalam Meningkatkan Kedisiplinan Di Kantor Kecamatan Gandus Kota Palembang dapat disimpulkan sebagai berikut:

1. Peran kepemimpinan dalam meningkatkan kedisiplinan pegawai Di Kantor Kecamatan Gandus Kota Palembang telah terlaksana dengan baik. Hal ini telah sesuai dengan prosedur-proseduryangada.

2. Peran Pemimpin sangat berpengaruh dalam peningkatan kedisiplinan kerja pegawai Di Kantor Kecamatan Gandus Kota Palembang guna mencapai keberhasilan kerja sebagaimana dengantujuanawalinstansi.

3. Didalam pelaksanaan disiplin kerja seringkali ditemui hambatan oleh pimpinan. Adapun hambatan yang ditemui di Kantor Kecamatan Gandus Kota Palembang adalah kurangnya kesadaran diri dan kurangnya tanggung jawab yangdimilikiparapegawai.

\section{SARAN}

Untuk mengatasi hambatan tentang kurangnya kesadaran dan kurangnya tanggung jawabini,Camathendaknyamelakukan pembinaan untuk meningkatkan disiplin kerja pegawai dengan penyampaian motivasi dan pendekatan lebih intensif kepada para pegawai yang bermasalah dengankedisiplinan.

\section{DAFTAR PUSTAKA}

Almitraf. 2015. Peningkatan Disiplin Kerja oleh Pimpinan dalam Organisasi. Jurnal
Administrasi Pendidikan, Vol.3, No.1, p.65759

Gomes,Fustino C. 2002. Manajemen Sumber Daya Manusia. Yogyakarta: Andi Offset

Hani, Handoko T. 2003. Manajemen Personalia dan Sumber Daya Manusia. Yogyakarta: BPFE

Hasibuan, Malayu. 2002. Manajemen Sumber Daya Manusia. Jakarta: Bumi Aksara

Heidjrachman dan Suad Husnan. 2002. Manajemen Personalia. Yogyakarta : BPFE

Kartono, Kartini. 2005. Pemimpin dan Kepemimpinan. PT. Raja GrafindoPersada. Jakarta.

.2003. Pemimpin Dan Kepemimpinan.
Jakarta :PT. Raja Grafindo. Persada

Lexy Moleong. 2007. Metodologi Penelitian Kualitatif. Rosda. Bandung

Mathis, Robert L dan John H Jackson, 2000.Manajemen Sumber Daya Manusia. Jakarta:PT. Salemba Empat.

Peraturan Pemerintah Nomor 30 Tahun 1980 tentang Disiplin Pegawai Negeri Sipil

R. Wiryana dan Susilo Supardo. 2005. Kepemimpinan Dasar-dasar dan Pengembangan.Yogyakarta:Penerbit Andi

Siagian, Sondang P. 1982. Manajemen Sumber DayaManusia.Jakarta:Bumi Aksara 2003. Manajemen Sumber DayaManusia.Jakarta: Bumi Aksara

Simamora, Henry. 2004. Manajemen Sumber Daya Manusia. Jakarta: Bumi Aksara

Sutrisno, Edy. 2009. Manajemen Sumber Daya Manusia. STIE YKPNMYogyakarta : Prenda Media Group

Undang-Undang Nomor 43 Tahun 1999 Tentang Pokok-Pokok Kepegawaian. 